\title{
Battery Power Control and Monitoring System with Internet of Things Technology
}

\author{
Didik Dwi Suharso \\ Teknika major \\ Merchant Marine Polytechnic \\ Surabaya, Indonesia \\ didik.suharso@poltekpel-sby.ac.id \\ Hendra Purnomo \\ Teknika major \\ Merchant Marine Polytechnic \\ Surabaya, Indonesia \\ hendrapoltek35@gmail.com
}

\author{
Slamet Winardi \\ Computer System major, Faculty of Computer Science \\ Narotama University \\ Surabaya, Indonesia \\ slamet.winardi@narotama.ac.id \\ Arief Budijanto \\ Computer Technology major \\ NSC Polytechnic \\ Surabaya, Indonesia \\ ariefbdi212@gmail.com
}

\begin{abstract}
Along with the development of battery/ACCU technology, the ACCU charging and loading system has also developed manually or automatically. In this paper, the results of research on the manufacture of tools that function to monitor and control the charging and loading of electrical power will be explained from batteries that are burdened with lights and DC motors through a control panel or android smart phone with IoT technology. This tool is designed to monitor 2 ACCUs, namely ACCU1 and ACCU2. ACCU1 is loaded with lamp and parallel with DC motor load while ACCU2 is loaded with DC motor and parallel with lamp load. If ACCU1 and ACCU2 are full, ACCU1 is loaded with only one lamp and ACCU2 is only loaded with DC motor. For example, ACCU1's electrical power is still within the limits that can be loaded with lights and DC motors while ACCU2 can't be loaded because electric power is not capable of being loaded with DC motors, the DC motor's load will be transferred to ACCU1. So that ACCU1 is loaded with DC lamps and motors and ACCU2 is charging the electricity, as well as for the opposite condition. The design of this tool uses the main component of the ESP32 microcontroller, where this component has been integrated with the wifi module and other supporting circuit modules, namely the current sensor circuit, voltage sensor and OLED display. The software design consists of a program code designer for hardware using $\mathrm{C}++$ and an android smart phone application design using MIT App Inventor. The results of this study are in accordance with the design specifications, namely the device can be used to control charging and loading as well as monitor ACCU1 and ACCU2 electrical power on OLED screens and on Android smart phones screens.
\end{abstract}

Keywords- ESP32, ACCU Charging, ACCU Loading, Firebase, IoT

\section{INTRODUCTION}

Information technology is currently developing very rapidly, one of which is the development of the Internet of Things (IoT). IoT itself is emerging as a big issue on the Internet. It is expected that billions of physical things or objects will be equipped with various types of sensors connected to the internet through networks as well as technology support such as embedded sensors, radio frequency identification (RFID), wireless sensor networks, real-time and web services, IoT actually cyber physical systems or networks. from the network. With the large number of things/objects and sensors/actuators connected to the internet, massive and in some cases real-time data streams will be automatically generated by the connected things and sensors. Of all the activities that exist in IoT is to collect the right raw data in an efficient way, but more important is to analyze and process the raw data into more valuable information.

With the above description of IoT, a study was made that applies this technology to the manufacture of a monitoring tool for current, voltage and electric current conditions in batteries wirelessly displayed on a smart phone screen via the internet so that before it runs out it can be recharged. In this study the Battery Status Monitoring System during charging and loading uses ESP32 \& IoT Cloud. Using this system, you can monitor battery voltage and percentage from anywhere in the world. Therefore, this system is useful for monitoring the battery charge/discharge status remotely.

As we know, the battery in any system or device is the main component, as it provides power to the entire system. Therefore, it is necessary to monitor the battery voltage level. So everyone knows that an improper charging and discharging system can cause battery damage or system failure. Most electrical/electronic devices have a Battery Management System (BMS). Actually, BMS monitors all battery properties like system voltage, current $\&$ auto disconnection. 


\section{LITERATURE REVIEW}

\section{Previous Research}

storage of the electrical energy system to the battery through a buck converter circuit controlled by Arduino using the PWM method to stabilize and lower the voltage of 14.4 Volts so that it does not exceed the battery charging threshold of $14.4-15$ VDC so that the battery lasts longer.[1]

The Battery Charger with a Non-Synchronous Buck Converter circuit is able to charge a 5 Volt Power Bank with a charging voltage of 6.25 Volt, a current of $0.15 \mathrm{~A}$, a battery temperature of $28^{\circ} \mathrm{C}$ with a charging time of 3 hours 21 minutes and is able to charge a 12 Volt battery with a voltage charging $13.5 \mathrm{~V}$, current 0.68 , Battery temperature $34^{\circ} \mathrm{C}$ with a charging time of 4 hours 37 minutes.[2]

To shorten the battery charging time, a DC to DC converter circuit with a high frequency of around $100 \mathrm{~Hz}$ is needed using a coil that has a low inductance value.[3]

Once the backup battery is fully charged, the PWM pulse width will decrease to near zero. During this stage, the controller will only sense battery voltage. The main advantage of this process is to increase battery life.[4]

\section{RESEARCH METHODS}

The methodology in the research of making tools for monitoring current, voltage and power conditions in batteries is carried out in the laboratory. The stages of the research are described in the form of a fishbone diagram shown in Figure 1.

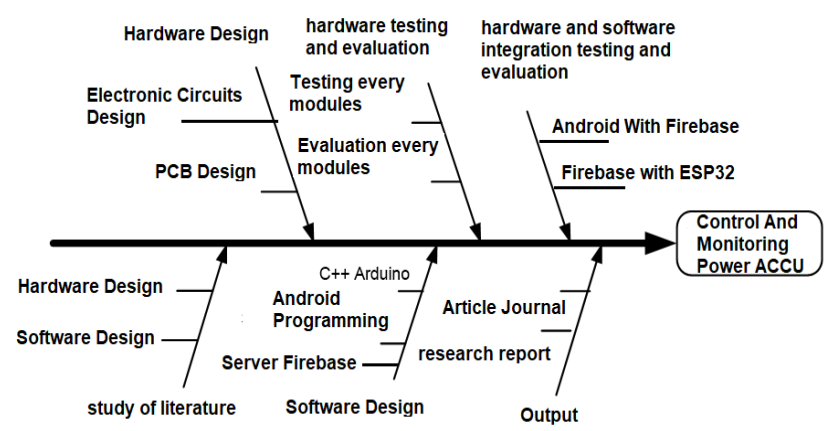

Fig. 1. Diagram of the Stages of Research Implementation

\section{Literature study}

Literature study is done by searching and collecting literature from various available sources including: reference books, scientific journals, and webside.

2. Hardware Design

Design of electronic circuits that support the manufacture of monitoring tools which include the design of a current sensor circuit, a display voltage sensor circuit and a data processing center circuit.

\section{Software Design}

Software design that supports the creation of a battery monitoring tool that uses $\mathrm{C}++$ and Android Block Coding.

4. System testing and evaluation

Testing and evaluation is carried out in 2 stages as follows:

- Testing per hardware module that is integrated with the software and evaluating

- Overall system testing and evaluation.duration per motorized vehicle based on the width of the road. To determine the count of traffic lights is as follows:

\section{A. Hardware Design}

The hardware block diagram can be seen in Figure 2. This tool is designed with the function of monitoring the current, voltage and power conditions of the battery that is displayed on the OLED viewer and on the smartphone screen. The design of the tool uses the main component of the ESP32 microcontroller, where this component is integrated with the wifi module and other supporting circuit modules, namely the current sensor circuit, voltage sensor and OLED display.

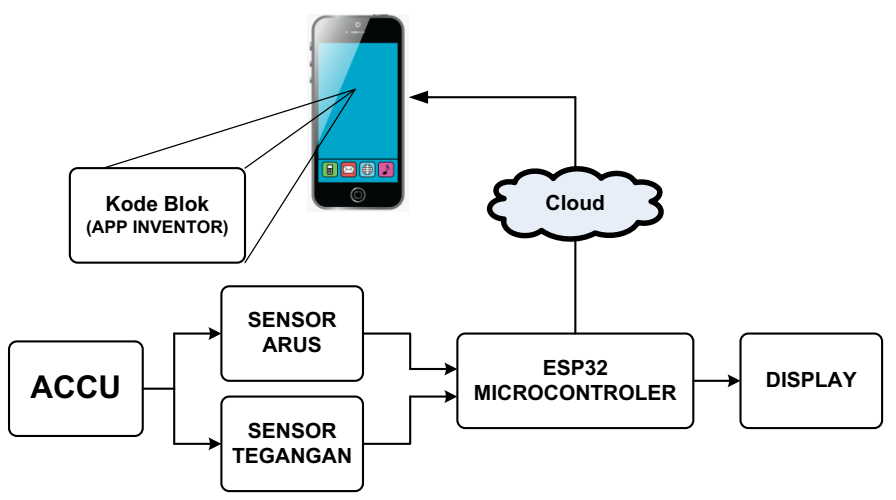

Fig. 2. Block Diagram of control and monitoring of electrical power on Accu

\section{B. Software Design}

Software design consists of 3 parts as follows:

- The software used for ESP32 is $\mathrm{C}++$ which is designed using Arduino IDE.

- Google Server Software with Firebase as a place to store data as well as a bridge between ESP32 and Android

- The software used in making mobile applications on smartphones uses Android App Inventor.

The following software design flowchart can be seen in Figure 3 


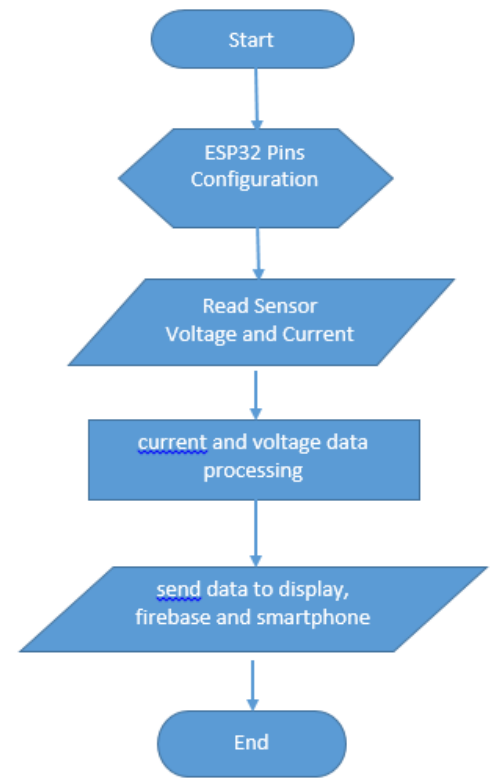

Fig. 3 Flowchart of Accu Power Monitoring Software

\section{RESULT AND DISCUSSION}

The results of the research include hardware implementation consisting of several electronic circuits and software implementation in the form of Arduino $\mathrm{C}++$ coding and android programming-based mobile applications. The description of the monitoring and control tool for ACCU charging can be seen in Figure 5. and the detailed discussion of the results of the research is divided into 2 parts, namely:

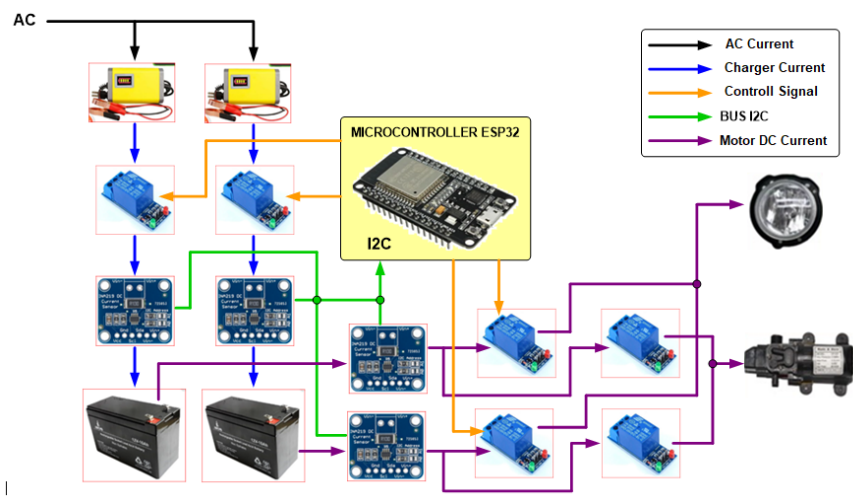

Fig. 4 ACCU Charging Monitoring and Control Tool Design

\section{A. ACCU Charge Control Circuit}

The ACCU charging process automatically by monitoring the current and voltage can control high-voltage electronic devices using relays. A relay is actually a switch that is operated electrically by an electromagnet. The electromagnet is activated with a low voltage, if the output pin 33 is in a logic "LOW" condition then there is a current flowing from $+5 \mathrm{~V}$ through $\mathrm{R} 4, \mathrm{D} 1, \mathrm{U} 1, \mathrm{D} 2$. Because there is a current through the optocoupler (U1), Q1 gets a $+5 \mathrm{~V}$ bias voltage because the $\mathrm{C}-\mathrm{E}(\mathrm{VCE}=0 \mathrm{~V})$ of the optocoupler is in a saturated condition, causing C-E Q1 to be saturated as well. When the Q1 condition is saturated, there is a current flowing through the relay coil so that the relay switch is in the $\mathrm{ON}$ condition (ACCU1 charging process). If the output pin 33 is in a "HIGH" logic condition, the opposite condition will occur, namely the ACCU1 charging process does not occur. The same process will also be carried out in the ACCU2 charging process. To control the charging process for ACCU 1 and ACCU2, the program has been uploaded to the ESP32 microcontroller chip.

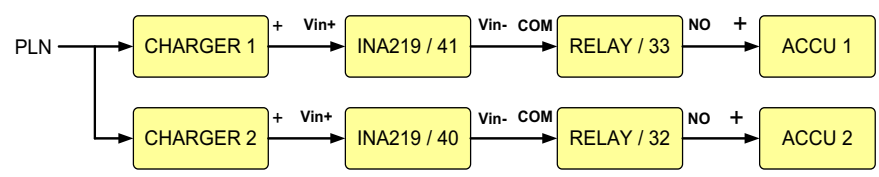

Fig. 5 . ACCU Charge Control

During the charging process, the current capacity stored in the ACCU is also monitored through the INA219 current sensor. Then the current sensor data measured by the INA219 sensor is sent to the Arduino microcontroller. The rus data is used to make decisions for charging ACCU to be continued or disconnected through the relay.

Fig. 6 Schematic of ACCU Charge Control

\section{B. Current Sensor Circuit}

The current sensor circuit used in the ACCU power monitoring system using the INA219 chip is shown in the following figure.

Fig. 7 INA219 Sensor Circuit 
The current sensor circuit design in Figure 8 can measure the current, voltage, and power of a circuit. The INA219 sensor is a sensor that functions to measure 2 parameters at once, namely voltage (volts), current (amperes), power (watts) and can also detect shunt voltage. This sensor series has been widely sold in the form of the INA219 Sensor Module produced by the Adafruit company. This sensor module is equipped with 0.1 ohm, $1 \%$ shunt resistors to meet current measurement requirements. The voltage that can be measured is up to $26 \mathrm{v}$ while the current is up to $3.2 \mathrm{~A}$. For communication, this sensor uses I2C, namely SDA and SCL. The INA219 Current Sensor can be easily used with Arduino to measure current, power. The display of the sensor module can be seen in Figure 9.

Fig. 9 INA219 Sensor

\section{ACCU Power Monitoring Circuit}

The process of monitoring the ACCU automatically by monitoring the current, voltage and power supplied to the lamp and pump loads can be seen in the ACCU usage monitoring block diagram in Figure 10. If the power in ACCU1 is at a minimum, then relay/27 and relay parallel /14 is in an open condition (not connected to the lamp and pump load), then ACCU1 is charged, ACCU2 provides power to the pump by activating (connected) relay/26 and the lamp by activating parallel/26 relay. Then conversely, if on the contrary ACCU2 is at a minimum limit condition, then relay/26 and relay parallel/25 are open, then charging ACCU2, ACCU1 provides power to the pump by activating relay/27 to activate the lights and relay parallel/14 to activate pump. The realization of the monitoring circuit can be seen in Figures 11. and 12.

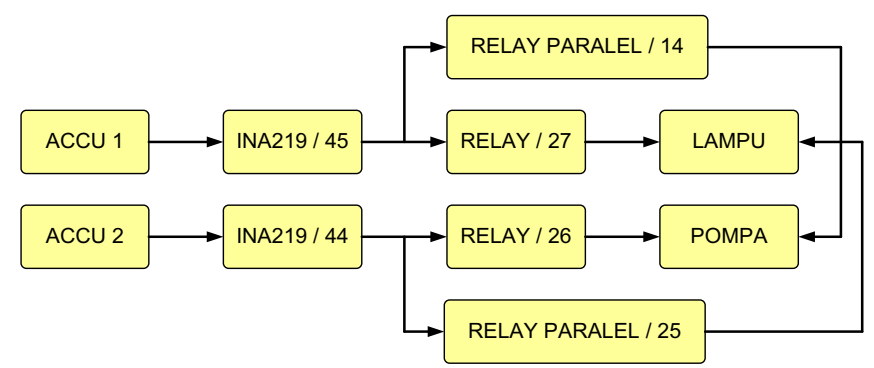

Fig. 10 ACCU Power Monitoring
Fig. 11 ACCU_1 Power monitoring circuit

Fig. 12 ACCU_2 Power monitoring circuit

\section{Software Implementation For Control Center}

Software implementation for ACCU charging control and monitoring center with ESP32 Microcontroller component using $\mathrm{C}++$ programming language and using Arduino IDE as the media editor. The following software implementation is divided into several parts program functions:

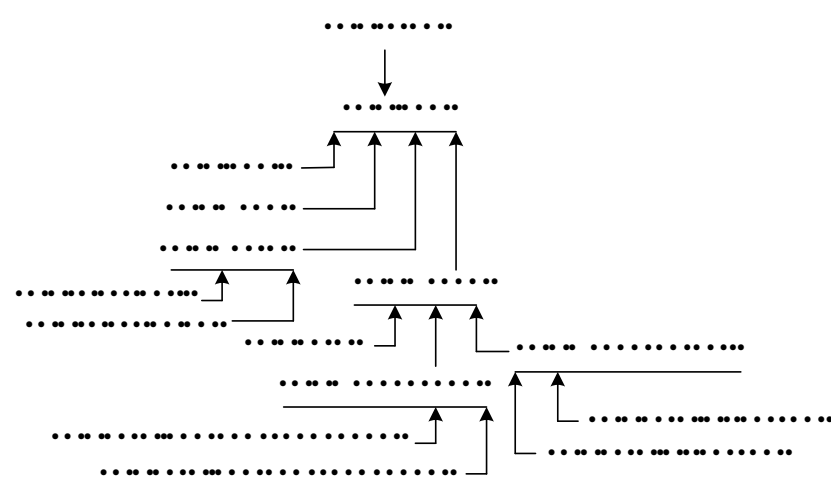

Fig. 13 Control Center Program Code Structure

\section{E. Implementation of Mobile Phone Application Software Design}

Software design to create applications on mobile phones using the Android MIT APP Inventor which consists of a viewer design and block code. Viewer design is a user interface design that will appear on the mobile phone screen. The viewer design of the ACCU power monitoring 
application can be seen in Figure 14. While the block code design consists of several parts, namely:
The test results when charging ACCU1 and ACCU2 the condition of the voltage, current and power parameters displayed on the OLED screen can be seen in Figure 16.

Fig. 16 Info Display Pada saat Mengukur

Fig. 17 Charger Testing in the Process of Charging to ACCU

Fig. 14 Interface design ACCU power control and monitoring software

\section{F. Testing}

Testing of ACCU control and monitoring tools can be carried out through the circuit panel directly or through an application installed on a mobile phone. A photo of the device can be seen in Figure 15.

Fig. 15 Photo of Trainer ACCU Charging and Monitoring Control
Fig. 18 Install Lamp Load on ACCU 1 and ACCU 2 with DC Motor

Fig. 19 ACCU 1 and ACCU2 Charging Process 


\section{CONCLUSION}

Based on above result, the conclusion is as follows:

1. In this research, the maximum current that can be measured is $3.5 \mathrm{~A}$ according to the sensor used, namely the INA219 type.

2. The INA219 sensor is able to output measurement data in the form of Bus Bar Voltage (voltage at the charger source or at the Accu source), Voltage drop at the shunt voltage sensor, load voltage, charging current and battery usage (current), and battery power ( Powers).

3. Control and monitoring can be done using an Android smartphone with Internet of Things technology connected to a Google server, namely Firebase.

4. The Accu Power Control System uses an Android smartphone programmed using the MIT App Invntor 2 programming language.

5. Control and monitoring can be done anywhere to see the battery status through the internet network connected to the Google server (Firebase).

\section{ACKNOWLEDGMENT}

Thanks to PPPM who has provided research grant funds so that we can submit paper in a international journal. Thanks also to the Director of Merchant Marine Polytechnic Surabaya who has given our support to submit paper in a international journal.

\section{REFERENCES}

[1] Hafelzan Enang Edovidata , Aswardi "Perancangan Sistem Pengisian Accumulator Mobil Listrik dengan Sumber Listrik Solar Cell Berbasis Mikrokontroler", JTEV (Jurnal Teknik Elektro Danvokasional), Volume 6 Number 1 (2019), ISSN: 2302-3309
[2] Ariel Firmansyah, I Nyoman Wahyu Satiawan , Syafarudin C.H, "Design Of System Charger Battery Using Mikrokontroller Whit Buck Converter Circuit", repository Universitas Mataram http://eprints.unram.ac.id/id/eprint/7000, 2021

[3] Ari Murtono, Edi Sulistio Budi, Herman Hariyadi, "Gelombang listrik amplitudu tinggi dan variasi frekwensi ripple untuk untuk mempercepat pemuatan charger aki basah”, JURNAL ELTEK Vol. 18, No. 1, April 2020, hal. 94 107 p-ISSN: 1693 - 4024 | e-ISSN: 2355-0740

[4] E Mulyana*, T D Atmoko and L Kamelia, "The automatic battery charger based on floating technique", 4 th Annual Applied Science and Engineering Conference IOP Publishing, Journal of Physics: Conference Series $1402 \quad$ (2019) 044029 doi:10.1088/1742$6596 / 1402 / 4 / 044029$

[5] Junaidi, A. "Internet Of Things, Sejarah, Teknologi Dan Penerapannya : Review". Jurnal Ilmiah Teknologi Informasi Terapan. Volume I, No 3, pp.62-66.2015.

[6] Ratnasari, T. Senen A. Prototipe Alat Ukur Arus Listrik Ac Dan Dc Berbasis Mikrokontroler Arduino Dengan Sensor Arus Acs-712 30 Ampere., Jurnal Sutet Vol. 7 No.2, pp. 28-33.2017.

[7] Satya T.P., Puspasari, F., Prisyanti H. , Saragih E.R.M, Perancangan Dan Analisis Sistem Alat Ukur Arus Listrik Menggunakan Sensor Acs712 Berbasis Arduino Uno Dengan Standard Clampmeter, Jurnal SIMETRIS, Vol. 11 No. 1, pp. 39-44. 2020.

[8] INA219 Zerø-Drift, Bidirectional Current/Power Monitor With I2C Interface, Texas Instruments Incorporated,2015

[9] Budijanto, A., Winardi, S., Susilo, K.E., Interfacing Dengan ESP32, Scopindo Media Utama, 2021

[10] Gaddis, T., Halsey, R., Starting Out With App Inventor for Android, Pearson Education Limited, 2015.

[11] ESP32 Techninal Reference Manual, Espressif Systems, 2021 